\title{
Correlation Between Determinant Factors and Early Initiation of Breastfeeding Practice in UPT Nglipar 1 Public Health Center
}

\author{
Suci Musvita Ayu*, Winda Juliani Hergianingrum \\ Faculty of Public Health, Universitas Ahmad Dahlan Yogyakarta, Indonesia \\ *corresponding author, e-mail:suci.ayu@ikm.uad.ac.id
}

Received: 07/11/2020; published: 30/03/2021

\begin{abstract}
Background: The coverage of Early Initiation of Breastfeeding (EIB) in Public Health Centers in Gunung Kidul Regency was $84.79 \%$. Unit Pelaksana Teknis (UPT) Nglipar 1 Public Health Center has an EIB coverage of $75.86 \%$. The amount is below the average of EIB coverage of all Public Health Centers in Gunung Kidul. This study aims to determine the factors that influence EIB at the UPT Nglipar 1 Public Health Centers. Method: The research employed observational analytic with a cross-sectional study design. The sample of this study was 45 mothers who were used as primary data. The sampling technique used to select participants was purposive sampling. Additionally, a questionnaire was also employed as research instrument. The population in this study were all mothers who gave birth in the UPT Nglipar 1 Public Health Center's working area. The study's independent variables were the mother's knowledge, husband's support, and health personnel support. The dependent variable is the Early Initiation of Breastfeeding. The data were analyzed using the chi-square method. Results: The results suggested that the relationship between maternal knowledge and EIB was indicated with $\mathrm{p}$ value $<0.05$. It showed that there was no relationship between partner support and EIB ( $p$-value $>0.05$ ). However, the data indicated that there was a relationship between health personnel support and EIB with $p$-value $<0.05$. Conclusion: The result of the study suggested that the variables under investigation showed different impacts. Maternal knowledge and health workers' support were the two variables which were correlated to EIB whereas partner support showed no correlation at all.
\end{abstract}

Keywords: Early Initiation of Breastfeeding (EIB); infant feeding practice; infant nutrition status

Copyright $(2013$ Universitas Ahmad Dahlan. All rights reserved.

\section{Introduction}

The nutritional status of infants or toddlers is an indicator of the level of community welfare. According to the health profile in Daerah Istimewa Yogyakarta (DIY) in 2018, Gunung Kidul Regency, ranked in the the first place in terms of Low Birth Weight (LBW) with 7.15\% and Kulon Progo Regency came second with 7.09\%. Malnutrition cases in Gunung Kidul Regency however, were the lowest of all regions in which it recorded $7.06 \%$ of cases. The highest percentage of malnutrition was observed in Kulon Progo Regency with $11.84 \%$. Toddlers with Under Redline Weight (URLW) are another nutritional problem that arises in DIY URLW is a standard commonly used to describe the nutritional status of children under five years of age. URLW can cause a decrease in endurance and it can interfere with the growth and development of children's physical, mental and brain networks. URLW does not indicate malnutrition but serves as a warning for follow-up confirmation. If toddlers with URLW status are not treated immediately, it will worsen the toddler's health and it eventually can cause death. The number of URLW cases in the Kulon Progo Regency in 2018 was the highest $(1.06 \%)$ and the city of Yogyakarta recorded $0.98 \%$ of the total cases [1].

Another nutritional problem in DIY is stunting. Stunting is stunted growth (growing short). Stunting is often closely related to socioeconomic conditions, exposure to a disease, and lack of nutritional intake both in its quantity and quality [2]. Stunted children are more 
likely to have delayed academic development as adults, are poor, less healthy, and are more susceptible to non-communicable diseases. The prevalence of stunting in Gunung Kidul Regency in 2018 was the highest with $18.47 \%$ and Bantul Regency, conversely saw the lowest prevalence $(9.75 \%)$ [1].

Early Initiation of Breastfeeding (EIB) is the beginning of the success of giving exclusive breastfeeding. EIB can strengthen mothers' effort to provide breast milk to their babies for up to 6 months. Giving breast milk from the beginning of birth allows the baby to get colostrum rich in immune substances [3]. Early Initiation of Breastfeeding is an important step to facilitate the baby in the breastfeeding process. The EIB process can start by placing the newborn on the mother's breast or stomach naturally and they can find the breast milk source to start breastfeeding. WHO recommends that the EIB process be carried out within the first hour of birth. Babies who get EIB will get colostrum rich in endurance, essential for infection resistance, intestinal growth, and even the baby's survival. The colostrum will create a layer that protects the baby's intestinal wall who is still immature and ripens the intestinal wall. Colostrum is the first milk that comes out. This gold liquid is also called the gift of life. Infants who are allowed to initiate early breastfeeding receive colostrum earlier than babies who are not given the opportunity [4].

Children who are not given early breastfeeding initiation within one hour of birth will have a higher risk of infection. A study showed that more than 4.000 children in Tanzania had been delayed early breastfeeding initiation and as a result, they experienced an increased risk of coughing. This further increased the risk of breathing difficulties in the first six months by $50 \%$ compared to children who received early breastfeeding initiation [5]. Early initiation of breastfeeding requires support from families, especially husbands. Indeed, fathers play a significant role and their role also significantly affects the EIB in offering exclusive breastfeeding [5]. The father's role largely determines the success of breastfeeding because the father will help determine the smoothness of the reflex for breastfeeding, which is strongly influenced by the mother's emotional state or feelings [6].

Studies show that husbands have been actively supporting the process of breastfeeding from EIB to exclusive breastfeeding. This is evident from the fact that as many as $72.7 \%$ of husbands support their wives in the process of breastfeeding [6]. Mothers need strong support so they can be motivated in carrying out positive behaviours influential to the health of the newborn. Additionally, support can come from third parties, namely, the husband, family, and health workers. The husband's support as a core family is very significant as they are the person closest to the mother [7].

There are several variables used in EIB. The participating mothers are those aged 2034 years $(76.9 \%)$, married $(86.9 \%)$, had done at least four antenatal care visits $(67.5 \%)$ and delivered vaginally $(78.3 \%)$ at $37-41$ weeks of pregnancy (89.7\%) [9]. Indonesia has an EIB coverage of $40.2 \%$. Indonesia supports an early breastfeeding initiation program. This is evidenced by the early breastfeeding initiation, which increased from $29.3 \%$ in 2010 to $34.5 \%$ in 2013 [8]. The coverage of early breastfeeding initiation in Public Health Center throughout Gunung Kidul was $84.79 \%$. However, Unit Pelaksana Tenis (UPT) Nglipar 1 Public Health Center has an early breastfeeding initiation coverage of $75.86 \%$, below the average Public Health Center throughout Gunung Kidul [9]. Based on UPT Nglipar 1 Public Health Center's EIB coverage data, the researchers are interested in researching this issue at UPT Nglipar 1 Public Health Center. The purpose of this study was to determine the factors that influence the Early Initiation of Breastfeeding (EIB) at UPT Nglipar 1 Public Health Center.

\section{Method}

This research is a quantitative observational analytic study using the cross-sectional survey method. This research was conducted at the Integrated Healthcare Center in Karangsari, Mangger, and Kwarasan Tengah areas, Gunung Kidul, Yogyakarta. The study was conducted in July 2019. The population used in this study were all mothers who gave birth in the working area of the Unit Pelaksana Teknis (UPT) Nglipar 1 Public Health Center from January to December 2018, consisting of 97 mothers. The sample was chosen using a purposive sampling technique. Additionally, there were several inclusion criteria used to choose the sample and one of which is mothers who give birth in the selected health center from January to December 2018. The participating mothers live close to the health centre, 
and mothers whose births are assisted by health personnel. The study exclusion criteria were pregnant women who had complications and mothers who were unwilling to become respondents. The sample of this study was 45 mothers who are used as primary data. This study's research instrument was a questionnaire adapted from several studies, namely a questionnaire regarding maternal knowledge, a questionnaire regarding the support of health workers for EIB and a questionnaire regarding husband's consent. In the questionnaire, 20 items were asked to research respondents. The analysis used in this research is bivariate analysis with the chi-square test.

\section{Results and Discussion}

\subsection{Result}

Based on Table 1 most mothers are junior high school and vocational high school (VHS) graduates (33.3\%) and the majority of them are housewives (86.7\%). The majority of husbands are senior high school graduates (53.3\%) and most of them work as labourers $35.6 \%$. More detailed profile of the participant can be seen in Table 1.

Table 1. Frequency Distribution of Respondent Characteristics

\begin{tabular}{lcc}
\hline Characteristics of the Respondent & $\mathbf{n}$ & $\%$ \\
\hline Mother education & 3 & 6.7 \\
Primary School & 15 & 33.3 \\
Junior High School & 25 & 55.5 \\
Senior High School & 15 & 33.3 \\
Vocational High School & 2 & 4.4 \\
University & & \\
Mother work & 2 & 4.4 \\
Teacher & 1 & 2.2 \\
Private employees & 4 & 8.9 \\
Farmer & 39 & 86.7 \\
Housewife & & \\
Husband's education & 3 & 6.7 \\
Primary School & 16 & 35.6 \\
Junior High School & 24 & 53.3 \\
Senior High School & 17 & 37.8 \\
Vocational High School & 2 & 4.4 \\
University & & \\
Husband's work & 1 & 2.2 \\
Village Apparatus & 1 & 2.2 \\
Government Employees & 2 & 4.4 \\
Private Employees & 3 & 6.7 \\
Employees & 7 & 15.6 \\
Entrepreneur & 15 & 33.3 \\
Farmer & 16 & 35,6 \\
Labourer & & \\
\hline
\end{tabular}

Based on Table 2 the majority of mothers have low knowledge $(51.1 \%)$. It is observed that most husbands support their wife in doing EIB (64.4\%). Similarly, health workers also support the majority of mothers in conducting EIB (66.7\%). In contrast to this trend, the majority of mothers did not do EIB (55.6\%). More detailed information can be seen in Table 2. 
Table 2. Frequency Distribution of Univariate Analysis

\begin{tabular}{lll}
\hline \multicolumn{1}{c}{ Variable } & n & $\%$ \\
\hline Mother Knowledge & 23 & 51.1 \\
$\quad$ Low & 22 & 48.9 \\
$\quad$ Good & & \\
Husband's Support & 16 & 35.6 \\
$\quad$ Not Support & 29 & 64.4 \\
$\quad$ Support & 15 & 33.3 \\
Health Workers Support & 30 & 66.7 \\
$\quad$ Not Support & & \\
$\quad$ Support & 25 & 55.6 \\
Early Breastfeeding Initiation (EIB) & 20 & 44.4 \\
$\quad$ Not Conducting EIB & 20 & \\
\hline
\end{tabular}

The results of the bivariate analysis showed that there is a relationship between mother knowledge ( $\mathrm{PR}=2.033 ; 95 \% \mathrm{Cl}=1.111-3.718$; $\mathrm{p}$-value $<0.05)$, support of health workers $(\mathrm{PR}=1.846 ; 95 \% \mathrm{Cl}=1.141-2.987 ; \mathrm{p}$-value $<0.05)$ and Early Initiation of Breastfeeding. More details can be seen in Table 3.

Table 3. Bivariate Analysis Results of Determinant Factors in Early Initiation of Breastfeeding at UPT Ngelipar 1 Public Health Center

\begin{tabular}{|c|c|c|c|c|c|c|}
\hline \multirow{3}{*}{ Variable } & \multicolumn{4}{|c|}{$\begin{array}{l}\text { Early Initiation of } \\
\text { Breastfeeding (EIB) }\end{array}$} & \multirow{3}{*}{ p-value } & \multirow{3}{*}{ PR $(95 \% \mathrm{Cl})$} \\
\hline & \multicolumn{2}{|c|}{ No } & \multicolumn{2}{|c|}{ Yes } & & \\
\hline & $\mathbf{n}$ & $\%$ & $\mathbf{n}$ & $\%$ & & \\
\hline \multicolumn{7}{|l|}{ Mother Knowledge } \\
\hline Low & 17 & 73.9 & 6 & 26.1 & 0.025 & 2.033 \\
\hline Good & 8 & 36.4 & 14 & 63.6 & & $(1.111-3.718)$ \\
\hline \multicolumn{7}{|l|}{ Husband's Support } \\
\hline Not Support & 11 & 68.8 & 5 & 31.3 & 0.313 & 1.424 \\
\hline Support & 14 & 48.3 & 15 & 51.7 & & $(0.863-2.350)$ \\
\hline \multicolumn{7}{|c|}{ Health Workers Support } \\
\hline Not Support & 12 & 80 & 3 & 20 & 0.044 & 1.846 \\
\hline Support & 13 & 43.3 & 17 & 56.7 & & $(1.141-2.987)$ \\
\hline
\end{tabular}

\subsection{Discussion}

Previous research on EIB's factors suggests that the better the mother's knowledge about Early Initiation of Breastfeeding (EIB), the greater the mother's opportunity to do EIB. Similarly, the higher a mother's education, the higher the knowledge of EIB. Thus, this knowledge will push the mother to do EIB with their newborn child [10]. The results of the study showed that there was a significant relationship between the mother's knowledge and EIB. Mothers who did not do EIB were those who had low knowledge (66.7\%) and the percentage was relatively lower among mothers who had high knowledge (33.3\%) [11]. This study's results are in line with previous studies which suggest that there is a relationship between maternal knowledge and EIB [12]. The higher the mother's education, the more knowledge the mother has about EIB to perform EIB on her newborn child [10].

Early breastfeeding delay was caused by a lack of understanding of the mother (predisposing factors) about EIB. Other qualitative studies report that the predisposing factor to the failure of exclusive breastfeeding is the predisposing factor to the mother's lack of knowledge and experience and the enabling factor that is very important to cause a loss because the mother is not facilitated to do EIB [13]. Lack of mother's knowledge about EIB is due to lack of proper information about EIB and respondents' lack of concern about EIB. The data also suggest that the participating mothers who had little information about EIB did not have sense of curiosity to learn about EIB. Good knowledge about early breastfeeding initiation plays a role in the mother's decision to initiate early breastfeeding. It strengthens the mother's belief that early breastfeeding initiation will positively impact their baby [9]. 
This lack knowledge is arguably caused by lack of socialization from health workers and lack of interest from the respondents themselves to seek or learn new information about the understanding, procedures for implementation, and benefits of EIB. The education of respondents gives an effect on knowledge. Knowledge is also gained from the experience and information received [14]. The main obstacle is the lack of knowledge about EIB in mothers. A mother must have good knowledge of EIB.

Husband's support is not necessarily a risk factor for EIB. A mother may not obtain husband's support during childbirth and this is mainly true among families where the husband is working, especially for those who earn a living as fishermen who sometimes have not returned home for weeks. Suppose a husband knows the benefits of implementing EIB, they will tend to support his wife to provide EIB. Still, conversely to the husband who does not know about the benefits of implementing EIB, the husband will tend not to be in line with the EIB implementation program 30 minutes to the first hour of the baby's birth [14].

This study is not in line with other studies in that it shows a significant relationship between husband support with EIB. It was observed that the respondents who did not do EIB was higher, particularly among those who did not get husband support. This type of family accounted for $78.0 \%$. In sharp contrast, only $25.6 \%$ of mothers who received husband's support chose not to do EIB. Husband's support in EIB's success is highly expected because there are still many women whose decision-making is influenced by their husbands, including breastfeeding. The husband's low understanding of the importance of EIB eventually hinders the implementation of EIB. Husband has never been educated about EIB and considers knowledge of pregnancy and childbirth as a mother's duty. The husband is only responsible for escorting and accompanying the mother to check pregnancy and childbirth [13]. Various factors, such as husbands, cause a lack of support from husbands in implementing EIB are busy working, lack of communication and husband's views are not correct. Husbands believe that wives know better what is best for mother and baby so that it gives the impression that the husband does not want to be further involved in childbirth problems [9].

The chi-square test examining the relationship between health personnel support with EIB showed the $p$-value of $0.044(p<0.05)$, which means there is a relationship between health personnel support and EIB. The RP value obtained is 1.846 with a value of $(95 \% \mathrm{Cl}) 1.141-2.987$, which means that mothers who did not get support from health workers are 1.846 times more at risk of not having EIB than to mothers who got the support. RP value $(95 \% \mathrm{Cl})>1$ indicates that health workers' support is a risk factor for EIB. This is because the better an officer is in conveying the intentions, objectives, benefits and impacts of the EIB, the better the results will be achieved. Conversely, the less good the officer is in carrying out the tasks as charged, the less likely the result can be achieved optimally [14].

This study is in line with research that states a relationship between health workers' support with EIB $[11,15]$. The role of officers and families who support dramatically influences the attitude of mothers in EIB. If it can be conditioned on officers and families who support EIB, it is clear that mothers will do EIB. Family and husband support is essential in implementing EIB [16]. The role of health care facilities in breastfeeding practices related to the service unit management's commitment to give special attention to the EIB program is very influential in achieving the success of EIB. Their trust largely determines the availability of people doing EIB in midwives [9].

Childbirth assistance is the main key to EIB's success. During this time, the role and support of childbirth assistance are still very dominant. Suppose the childbirth helper facilitates the mother to hug her baby immediately. In that case, the interaction between mother and baby is expected to happen soon.

\section{Conclusion}

Based on the results and discussion, it can be concluded that the factors associated with low Early Initiation of Breastfeeding (EIB) at the UPT Nglipar 1 Public Health Center are maternal knowledge and support of health workers. In contrast, the unrelated factor is husband support. 


\section{References}

1. Dinas Kesehatan DIY. Profil Kesehatan D.I Yogyakarta tahun 2018. Profil Kesehat Drh Istimewa Yogyakarta tahun 2018. 2018;32.

2. WHO. Stunting Policy Brief. Switzerland: Department of Nutrition for Health and Development World Health Organization; 2014.

3. Ekaristi P, Kandou GD, Mayulu N. Hubungan Inisiasi Menyusui Dini (IMD) dengan Pemberian Asi Ekslusif di Kota Manado. J Kesehat Masy Univ Sam Ratulangi. 2017;6(3).

4. Martalia D. Pentingnya Peranan Seorang Bidan. Jakarta: Dunia Cerdas. 2017.

5. Smith ER et al. Delayed Breastfeeding Initiation is Associated with Infant Morbidity. $J$ Pediatr. 2017;191:57-62.

6. Kusumayanti, N. Nindya. T S. Hubungan Dukungan Suami dengan Pemberian ASI Eksklusif di Daerah Pedesaan. Indones Nutr Media J. 2017;12(2):98-106.

7. Ritasari M. Hubungan Inisiasi Menyusu Dini dengan Kecepatan Keluarnya Air Susu Ibu (ASI) pada Ibu Post Partum di RB Nilam Sari Tembilahan Kota. BAPPEDA J. 2017;3(2):74-81.

8. Kemenkes RI Badan Penelitian dan Pengembangan. Riset dan Kesehatan Dasar (RISKESDAS) Tahun 2013. Kementerian Kesehatan Republik Indonesia. 2013.

9. Lestari M. Analisis Faktor-Faktor yang Berhubungan dengan Pelaksanaan Inisiasi Menyusu Dini pada Ibu Bersalin di Klinik Bersalin Asih Waluyo Jati Yogyakarta. J IIm Kesehat Ar-Rum Salatiga. 2018;2(2):35-41.

10. Ulandari D. Faktor-Faktor yang Mempengaruhi Pelaksanaan IMD pada Pasien Pasca Persalinan di BPM Ratna Wilis Palembang Tahun 2016. J ilmu Kesehat. 2018;16(1):6472

11. Aryani. Faktor-faktor yang Berhubungan dengan Inisiasi Menyusu Dini di Wilayah Kerja Puskesmas Satelit Bandar Lampung. J Heal Panca Bhakti Lampung. 2018;6(1):31-51.

12. Pratiwi A. Hubungan Pengetahuan dan Sikap Ibu Nifas dengan Inisiasi Menyusui Dini. $J$ IIm Multi Sci Kesehat. 2019;10(2).

13. Ginting EPFZAS. Faktor-faktor yang Memengaruhi Kegagalan Inisiasi Menyusui Dini pada Ibu Post Sectio Caesarea di RS Tentara Binjai Tahun 2018. J Kesh Perin (Perin's Healt J). 2019;6(1):81-88.

14. Rusada, D.A, Sartiah Y NN. Faktor yang Berhubungan dengan Pelaksanaan Program Inisiasi Menyusu Dini (IMD) di Puskesmas Poasia Kota Kendari Tahun 2016. JIM Kesmas. 2016;1(3):1-9.

15. Wardhani, S. K, Chusnul C. Hubungan Dukungan Suami dengan Keberhasilan Inisiasi Menyusu Dini pada Ibu Bersalin di Klinik Bersalin Bu Nafsi Wonogiri. IJMS - Indones J Med. 2018;5(2):134-140.

16. Pangerapan NLAUHL. Faktor-faktor yang Berhubungan dengan Pelaksanaan Inisiasi Menyusu Dini (IMD) di RSUD Datoe Binangkang. J Public Health. 2017;2:52-57. 